\title{
EQUIPMENT FOR REMOTE MEASUREMENT OF \\ BOW, LENGTH, AND WEIGHT OF IRRADIATED \\ EXPERIMENTAL CAPSULES AND ELEMENTS AT EBR-II
}

by

J. W. Rizzie

\author{
EBR-II Project \\ Argonne National Laboratory \\ Argonne, Illinois - Idaho Falls, Idaho
}

\begin{abstract}
This report was prepared as an account of work sponsored by the United States Government, Neither the United States nor the linited Government. Nether Commission, nor nor the United States Atomic Energy Cheir contractors, any of their employees, nor any of makes any warranty legal liabity

pletentesponsibility for the accuracy

pleteness or usefulness of any information product or process disclosed, or represents that its use would not infringe privately owned rights.
\end{abstract}

June 1970

Work performed under the auspices of the U. S. Atomic Energy Commission 


\section{DISCLAIMER}

This report was prepared as an account of work sponsored by an agency of the United States Government. Neither the United States Government nor any agency Thereof, nor any of their employees, makes any warranty, express or implied, or assumes any legal liability or responsibility for the accuracy, completeness, or usefulness of any information, apparatus, product, or process disclosed, or represents that its use would not infringe privately owned rights. Reference herein to any specific commercial product, process, or service by trade name, trademark, manufacturer, or otherwise does not necessarily constitute or imply its endorsement, recommendation, or favoring by the United States Government or any agency thereof. The views and opinions of authors expressed herein do not necessarily state or reflect those of the United States Government or any agency thereof. 


\section{DISCLAIMER}

Portions of this document may be illegible in electronic image products. Images are produced from the best available original document. 


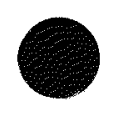

$F$

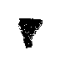

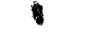


TABLE OF CONTENTS

Page

ABSTRACT. . . . . . . . . . . . . . . . . . 5

I. INTRODUCTION. . . . . . . . . . . . . . . 6

II. THE AIR CELL. . . . . . . . . . . . ........ 7

A. Remote Manipulation ................... 9

B. Radiation Damage and Remote Repair. . . . . . . . . . . 9

III. EQUIPMENT FOR MEASURING BOW AND LENGTH. . . . . . . . . . . . . 9

A. Stage . . . . . . . . . . . . . . . . . 11

B. Soft-touch sensor ..................... 11

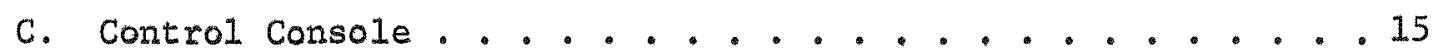

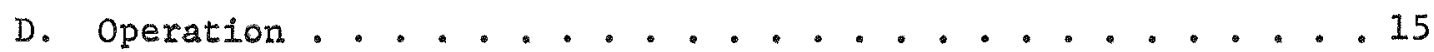

E. Ranges and Accuracy ................. 16

F. Standards ..................... 16

IV. REMOTELY CONTROLLED BALANCE ................... 17

A. Electronic Balance. . . . . . . . . . . . . . 17

B. Balance Stand... . . . . . . . . . . . . 18

C. Range and Accuracy. . . . . . . . . . . . . 18

D. Operation .................... 23

E. Weight-calibration Standards............... 23

V. FUTURE ADDITIONS TO EQUIPMENT . . . . . . . . . . . . . . 24

A. Bow and Length Equipment. . . . . . . . . . . . . 24

B. Remote Balance. . . . . . . . . . . . 25

REFERENCES. . . . . . . . . . . . . . . . . . 25 
No.

Title

$\underline{\text { Page }}$

1. Fuel Cycle Facility. . . . . . . . . . . . . . . . 8

2. Equipment for Measuring Bow and Length . . . . . . . . . 10

3. Top Support Plate of Bow and Length Stage. . . . . . . . . . . . 12

4. Pin Plate and Lower Bearing Plate of Bow and Length Stage. . . . 13

5. Scan Plate and $X-Y$ Soft-touch Bow Sensor of Bow and Length Stage. . . . . . . . . . . . . . . . . 14

6. Remote Balance Equipment .................. . 19

7. Electronic Balance . . . . . . . . . . . . . . . 20

8. Leveling System for Remote Balance Stand . . . . . . . . . . . 21

9. Capsule and Element Grapple. . . . . . . . . . . . . 22 


\author{
EQUIPMENT FOR REMOTE MEASUREMENT OF \\ BOW, LENGTH, AND WEIGHT OF IRRADIATED \\ EXPERIMENTAI CAPSULES AND ELEMENTS AT EBR-II
}

by

J. W. Rizzie

ABSTRACT

The measurement equipment is used in the air-ce11 complex of the Fuels and Examination Facility at the EBR-II site to support the irradiation program of the EBR-II Project. The device for measuring bow and length and the remotely controlled balance provide physical data from irradiated experimental elements or capsules that can be used to determine the experiment integrity and help evaluate the results of the irradiation cycle. A gross change in weight of an irradiated capsule or element before and after irradiation is a definite indication of a defected capsule or element cladding. Bow and length measurements are used to qualify capsules or elements for reconstitution (for continued irradiation in EBR-II subassembly form) and to analytically determine the stress exerted on the subassembly hexagonal tube by the enclosed elements or capsules.

The bow of the irradiated element or capsule is measured vertically by mechanically locating the centerline of the subject and comparing this location with the centerline of a known straight standard. Bow is mechanically encoded in $X$ and $Y$ coordinates and later converted to an angle and radius from a fixed position on the capsule or element. Lengths of capsules and elements are measured with a dial indicator, which is calibrated with a standard-length Invar rod.

Capsule and element weights are measured remotely using an electromechanical balance with digital readout. 


\section{INTRODUCTION}

The EBR-II Project operates and maintains the Experimental Breeder Reactor No. II (EBR-II) and the Fuels and Examination Facility (FEF). EBR-II is currently being used as a fast-flux irradiation facility in support of the fuel and cladding development activities of the Liquid Metal Fast Breeder Reactor (LMFBR) program.

The Fuels and Examination Facility provides capabilities for assembling and disassembling irradiated experiments and for making interim examinations for the experiment sponsor. Usually, an interim examination does not destroy the cladding or the experiment. After the capsules or elements are examined, they are reassembled into a subassembly for continued irradiation in EBR-II. Reassembly of the irradiated experiments is called reconstitution. ${ }^{1}$

The FEF currently consists of the former Fuel Cycle Facility (FCF), but it also will include the Hot Fuels and Examination Facilities (HFEF) now under construction. An inert-atmosphere argon cell (15 work stations) and an air cell ( 9 work stations) make up the FCF. The FEF complex now has available neutron radiography, a visual stereo-inspection station, diametermeasuring devices, photography, equipment for measuring bow and length, and weighing equipment for the interim examination of irradiated experiments. In the near future, reencapsulation, precision gamma scanning, profilometry, temperature-measuring devices, fiducial-measuring equipment, equipment for visual microscopic examination, and devices for eddy-current testing of cladding will be used in the FEF to strengthen its capabilities for interim examination.

The bow in irradiated capsules or elements is measured for two reasons:

1. To determine whether the bow will affect the reassembly into a subassemb $1 \mathrm{y}$; and,

2. To analytically reconstruct the stress that the bowed elements or capsules were applying to the hexagonal tube of the subassembly.

The bowing is determined by measuring change in all directions of the centerline axis of the irradiated capsule or element from the preirradiation position. The data are presented as an angle $(-180 \leq \phi<180)$ and a radius (mils). 
Length is measured to determine the change in the length of the unrestrained capsule. This measurement is related to bowing; it is not used to measure axial growth of irradiated capsules or elements, which should be measured by use of fiducial marks on the element or capsule.

The remotely controlled balance is used to weigh an irradiated capsule or element accurately and to display the weight digitally at the operator's control console. The weights before and after irradiation are compared to determine whether the capsule or element has changed in weight during irradiation-an indication of defected cladding. Intake or expulsion of reactor or bond sodium usually accounts for the weight change.

All new irradiation subassemblies continue to utilize the standard external dimensions common to driver-fuel subassemblies to insure compatibility with existing fuel-handling devices, such as the FEF assembly/disassembly machine. ${ }^{2}$

\section{THE AIR CELL}

The FCF air cell (see Fig. 1) is a radiation-shielded area with an air atmosphere. It is used for dismantling and assembling subassemblies so that the enclosed capsules or elements can be inspected and tested. Also, the area can be used to service equipment from the FCF argon cell (see Fig. 1). The cell is about $15 \mathrm{ft}$ wide, $47 \mathrm{ft}$ long, and $21 \mathrm{ft} \mathrm{high,} \mathrm{with} 5$-ft-thick cell walls of high-density reinforced concrete $\left(220 \mathrm{Ib} / \mathrm{ft}^{3}\right)$. There are nine operating bays in the cell, each located at a high-density, leadglass window. Pneumatic and electrical supply lines are brought into the cell through the air-cell floor and wall service sleeves. These services are connected remotely by using two master-slave manipulators at each of the nine operating bays. Half of one operating bay is allotted to the equipment for measuring bow and length and the remote balance.

Twenty-four 1000-W, 277-V mercury-vapor lights are mounted on the aircell wall for interior cell lighting. The cell ventilation system, with a flow of $6100 \mathrm{cfm}$, maintains the air pressure in the cell below that outside the cell. At the center of the air cell are ten shielded, air-cooled, subassembly-storage pits. 


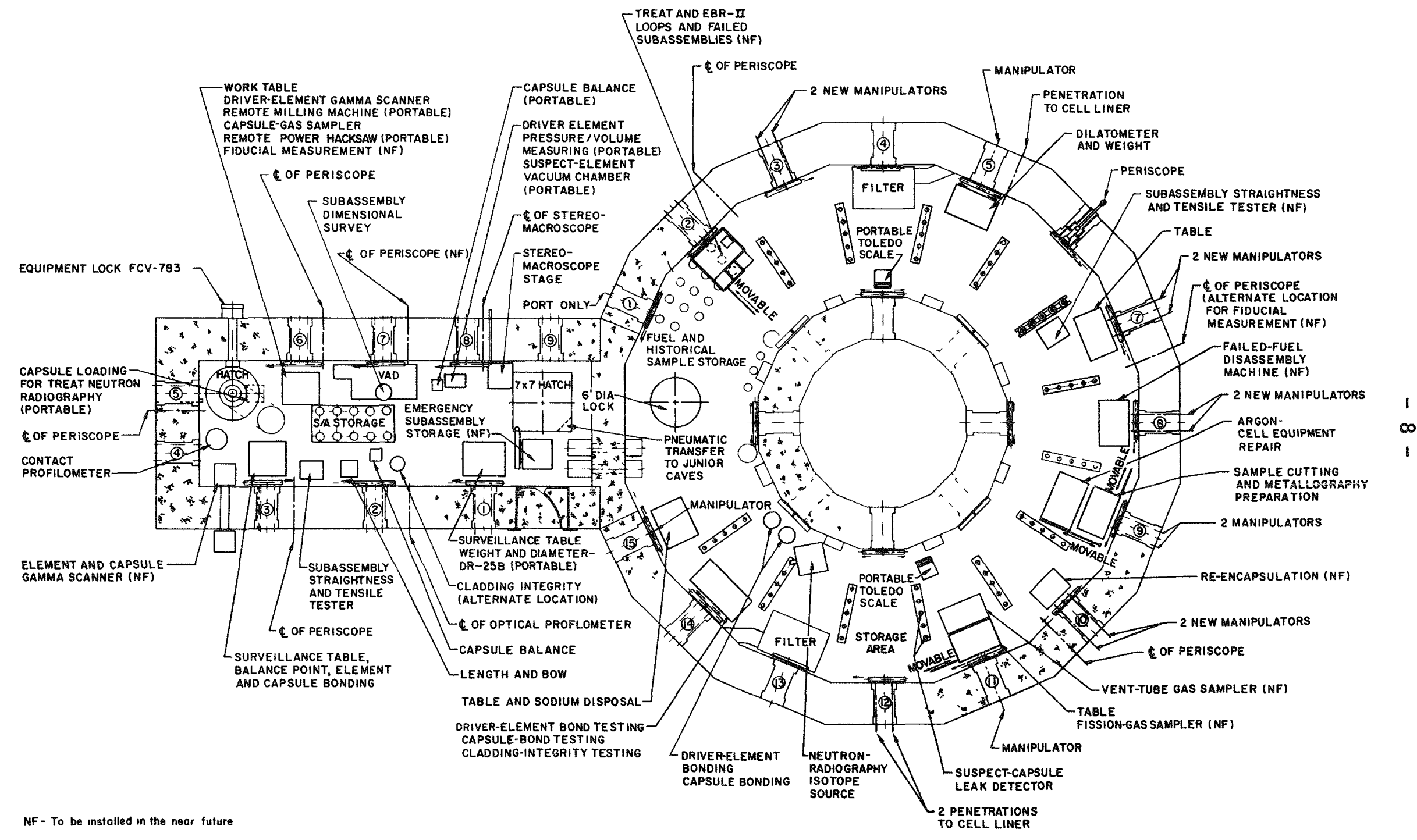

Fig. 1. Fuel Cycle Facility 


\section{A. Remote Manipulation}

Remote manipulation is provided by one 5-ton crane, two bridge-type operating manipulators, and nine sets of master-slave manipulators. The crane rails, which are 17 ft above the floor, pass over the manipulator rails. Two unilateral electric (unarticulated) manipulators pass under the crane but cannot pass each other. The manipulator rails are $13 \mathrm{ft}$ above the floor.

Because of the limited manipulation available, all repetitive operations are remotely controlled from the operator's window. All heavy lifting operations are designed to use rectilinear lifting motion only.

\section{B. Radiation Damage and Remote Repair}

The radiation level of $10^{6} \mathrm{R} / \mathrm{hr}$ within the air cell limits the selection of materials of construction. Use of organic materials, such as commercial paints, standard lubricants, sealing materials, and electrical insulation, must be avoided unless the specific item is easily replaceable. In some situations, a replaceable item with a known life must be used because of the expense of developing radiation-stable components. The bow-measuring device and remote balance were designed to minimize maintenance. All non-replaceable items were selected so that they would last the lifetime of the machine ( 3 years). For some parts, it was desirable to use ones that had a limited lifetime and make them replaceable. Because both the bow-measuring device and the remote balance are used in the FEF air cell, where plutonium contamination is at a low level, removing the devices from the cell for detailed maintenance and repair was judged to be less costly than designing the devices for total remote maintenance.

\section{EQUIPMENT FOR MEASURING BOW AND LENGTH}

The equipment is made up of an in-cell support frame (stage), softtouch sensor, and measurement standards. The out-of-cell equipment consists of a remote-control console and service feed-throughs (see Fig. 2). 


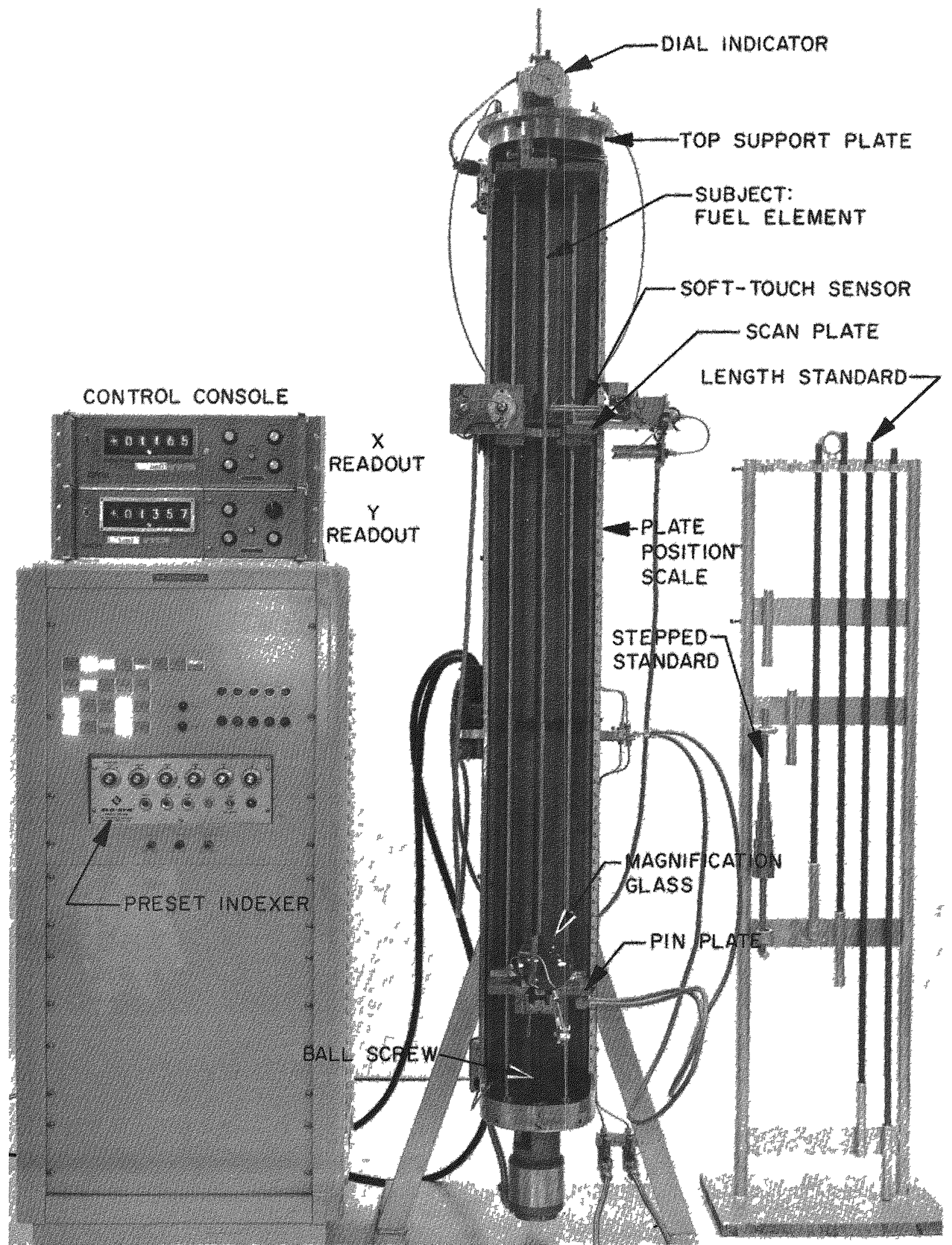

Fig. 2. Equipment for Measuring Bow and Length 


\section{A. Stage}

The stage consists of a support frame, ball-screw drivers, a pin plate, and a scan plate. The measuring system is supported inside an 8-in.-dia stainless steel pipe (half-shell) fitted at both ends with bearings and support plates for stepping motors. (See Figs. 3 and 4.) Both the pin plate (see Fig. 3) and the scan plate (see Fig. 5) are movable and are guided by ball-bushing shafts and V-block ways. The pin plate supports the capsule or element in a fixed orientation. The plate is moved by $20.200-$ in.-pitch, 3/8-in.-dia, ball screw driven by a stepping motor.

The subject is held in a fixed position at the extreme top and bottom by two V-blocks and pneumatically operated clamps (see Figs. 3 and 4). The clamping mechanism is designed so that no bow is introduced into the subject after it is clamped. A dial indicator (see Fig. 3) is used to measure the unrestrained length after the indicator has been calibrated with a standard rod.

\section{B. Soft-touch Sensor}

Obtaining an accurate bow measurement requires that the measurement device does not apply any perpendicular forces, which could deflect the subject to the side. Dial indicators were not used to measure bow deflection because the spring-loaded indicator sten would force the smaller-diameter subjects out of their natural position. The soft-touch sensor (STS) was designed to overcome the deflection problem.

The STS is mounted on the stage scan plate. It consists of two copper touch bars, which are driven in and out perpendicular to the axis of the subject (see Fig. 5). Each bar is electrically insulated from the machine frame. When a touch bar contacts the surface of the subject, an electrical circuit is closed. The closed circuit opens an electrical clutch and closes a brake in the drive system, and it automatically shuts off the variable-drive dc motor. Both touch bars travel in independent drive mechanisms (max speed 1 in./min). 


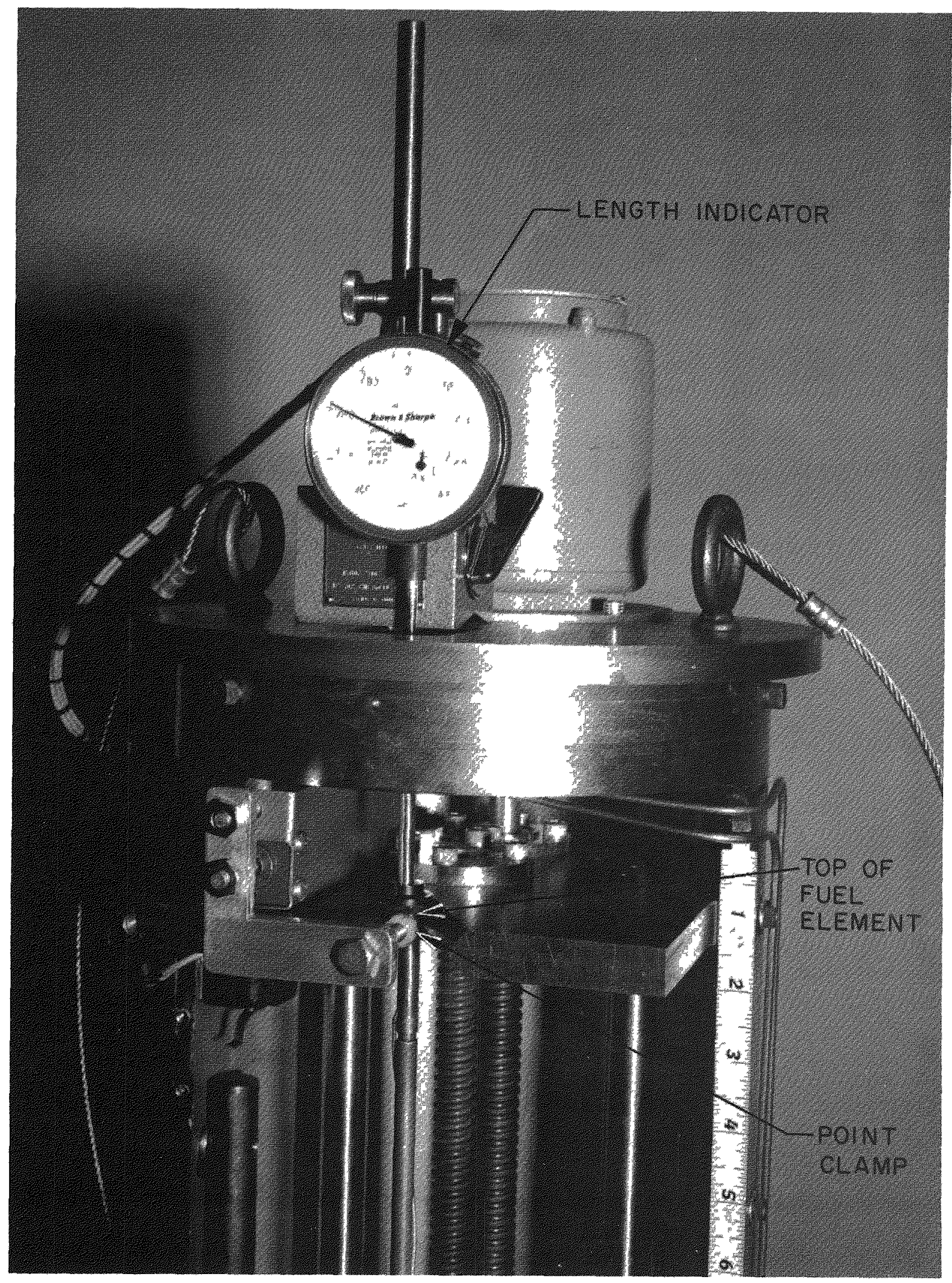

Fig. 3. Top Support Plate of Bow and Length Stage 

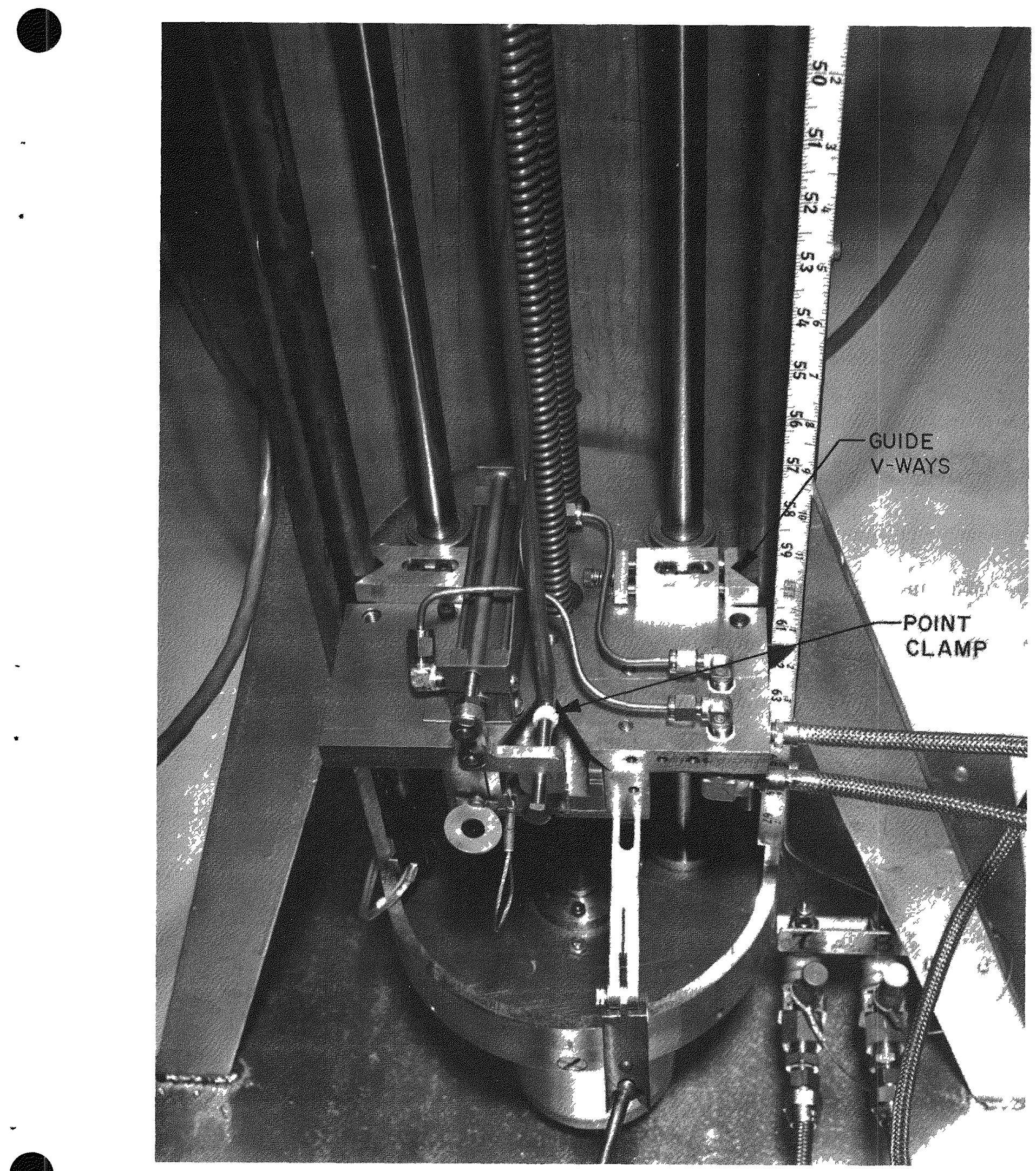

Fig. 4. Pin Plate and Lower Bearing Plate of Bow and Length Stage 


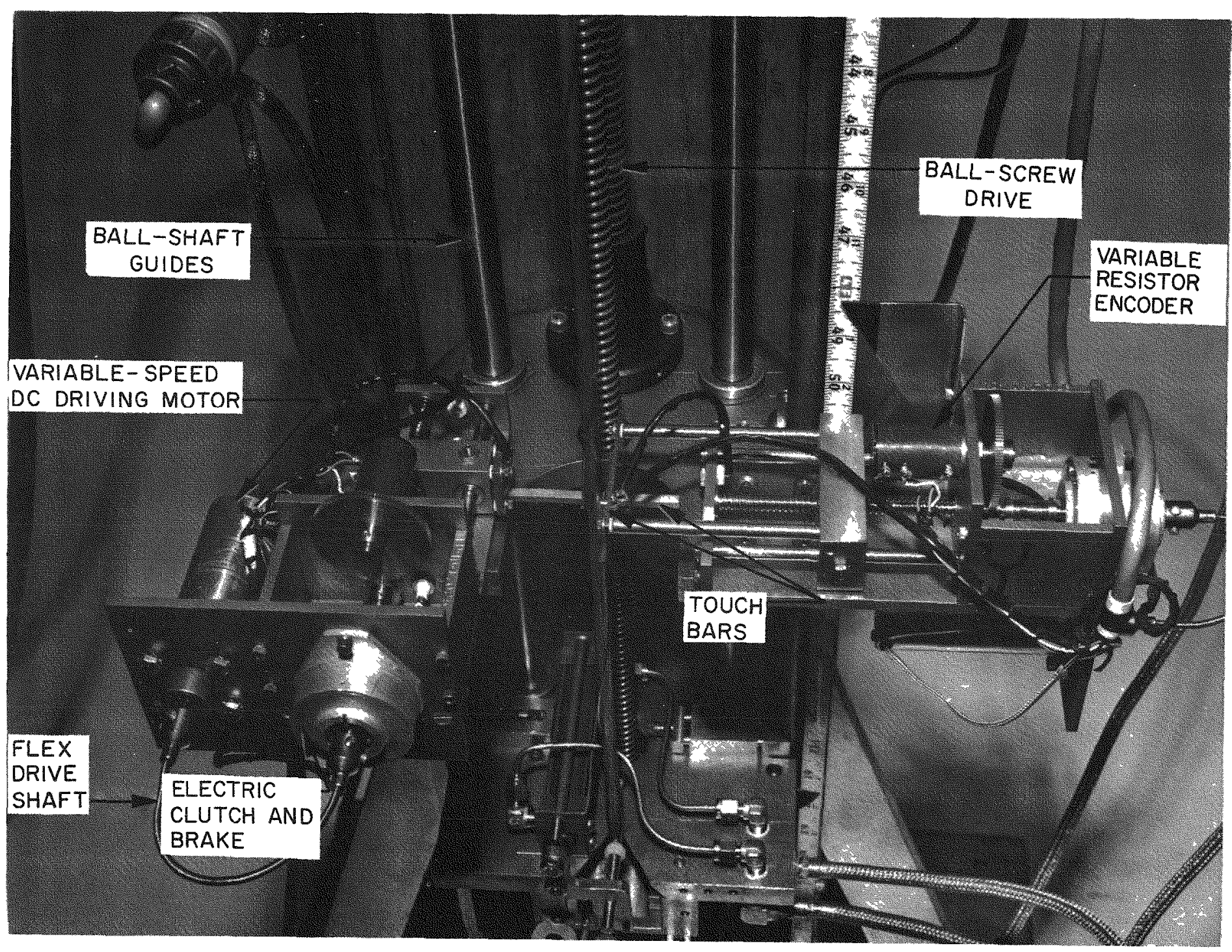

Fig. 5. Scan Plate and $X-Y$ Soft-touch Bow Sensor of Bow and Length Stage 
The distance the touch bar moves from its outer limit is encoded

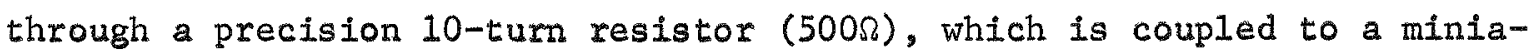
ture ball-screw drive by a gear system. Both touch bars have electricallimit contacts at the extreme end of the two travel directions.

\section{Control Console}

The control console (see Fig. 2), which is in front of the operator's shielding window, contains the readout of the soft-touch sensor, preset indexer, and control buttons. Interlocks built into the console wiring network will prevent improper operation of the equipment.

\section{Operation}

Measurement of bow and length is begun by moving the pin plate to a position corresponding to the length of the capsule or element (60-7/8 in.). The length standard is then placed in the machine between the two V-blocks and the pneumatic clamps are closed. The dial-indicator (see Fig. 3) reading is recorded. The length standard is then replaced with the subject. The deviation in the indicator reading represents the difference from the standard, and thus the length of the subject is determined by difference.

Bow is measured by moving the scan plate (with the touch bars at their outer limits) to about 6 in. above the lower spacer-wire weld of the element or capsule. This position is in phase with the spacer-wire pitch and assures that the touch bars will not contact the spacer wire and give an erroneous reading. From the time the touch bars are moved toward the subject until they reach their limit, their position is recorded. They are next backed away from the subject so that the scan plate can be moved up 6 in. Soft-touch sensor readings are taken about every 6 in. until the top of the pin is reached. If there is no spacer wire, readings can be taken at any position along the subject. The X-Y touch-bar reading (Cartesian coordinate) is converted to an angle $\left(-180^{\circ} \leq \phi<180^{\circ}\right)$ and a radius (mils), with the first reading used as a basis. This measurement is called a relative bow measurement because the radius is measured relative to some position on the capsule or element wall. An absolute bow 
measurement can be made by subtracting the measured bow reading from a reading obtained from a straight standard of the same diameter as the subject.

\section{E. Ranges and Accuracy}

The device can be used to measure the axial deviation of rods or tubes with diameters from 0.220 to 1.0 in. It can be remotely adjusted to measure subjects with lengths from 18 to 65 in. The maximum bow that can be measured depends on the diameter of the subject. For a 1-in.-dia subject, a maximum bow of $1 \mathrm{in}$. can be measured in any direction. For a 0.220-in.-dia subject (minimum size), a maximum bow of 1.39 in. can be measured in any direction.

Length measurements are limited only by the standards available. The dial indicator used to measure length has a range of 1 in.; therefore, a standard with a length within \pm 0.9 in. of the subject must be available. Standards are available for lengths of all capsules and elements now being used in EBR-II.

The repeatability of the bow measurement is $\pm 1 / 32$ in. for the radius and $\pm 0.1^{\circ}$ for the angle. The accuracy of the measurement (over 65-in. range) is $\pm 3 / 64 \mathrm{in}$. for the radius and $\pm 0.3^{\circ}$ for the angle. The repeatability of the $X-Y$ measurement is \pm 8 mils and its accuracy over the $65-i n$. range is $\pm 20 \mathrm{mils}$. Length measurements are accurate to $\pm 0.001 \mathrm{in}$.

\section{F. Standards}

A steel standard 18-in. 1ong (see Fig. 2) is used to calibrate the linear motion of the two touch bars. The standard is stepped in increments of $0.125 \pm 0.001 \mathrm{in}$. from 1/2 in. to $1-1 / 2 \mathrm{in.} \mathrm{Repeatability} \mathrm{of} \mathrm{the} \mathrm{mea-}$ suring system is also determined with the standard by runing the touch bars in and out with the standard in one position and noting the variation in the readings.

A smal1-diameter steel wire stretched between the two V-clamps is used to measure the precision of the device over the 65-in. travel of the scan plate. Any deviation of the touch-bar readouts over the travel span 
of the scan is the result of dynamic error in the STS and control system and misalignment of the subject clamps. Tubes with a known straightness per foot are also used to measure the equipment precision.

Calibrated Invar steel rods are used as primary standards to calibrate the in-cell secondary length standards.

\section{REMOTELY CONTROLLED BALANCE}

The remotely controlled balance is used in the FCF air cell to weigh irradiated capsules and elements. The weighing system (see Fig. 6) is made up of a commercially available electronic balance, support stand, capsule and element grapples, and feed-throughs in the air-cell wall.

\section{A. Electronic Balance}

The balance (Ainsworth Digimetric 1K) (Fig. 7) is a precision, fully automatic electronic balance. By use of mass-measurement transducers and solid-state electronic techniques, mass determination is converted to an electronic signal. This signal is displayed both visually and electronically to allow operation with external data-handling equipment.

The balance features speed, ruggedness, and high accuracy with the simplest operation. There are very few operating controls and no range switching is required throughout the full dynamic range, so that the balance is very useful for remote operation. The high-intensity "nixie"-tube readout and electronic-calibration and weight-decoding system are in a separate cabinet located in the cell operating corridor. A binary-coded decimal (BCD) output is provided at the back of the operating console. Both this output and the visual display may be held by either a panel switch or, upon command, from a remote source. The balance recomputes the weighing once every second and has a self-check calibration control table at the front panel. A tare system may be continuously adjusted in $100 \mathrm{~m}$ increments up to $300 \mathrm{~g}$. There is an overlap between the 3-tare switch ranges to insure continuous tare from $0-300 \mathrm{~g}$.

The in-cell portion of the balance consists of the fulcrum mechanism, weighing pan, suspension weighing hook, null-balance system, and cabinet. When a weight is placed on the fulcrum mechanism, an electro-coil is displaced 
from an electromagnetic null position. The magnet transmits a signal to a module for more current to pull the coil back into the null position. The module supplies the required current to null the coil. This current and its associated voltage is then decoded into grams on the remote readout display.

The in-cell portion of the balance, which can be removed from the balance stand, is stored out-of-cell when not in use. A fulcrum-arresting mechanism is used to protect the mechanical system during movement.

\section{B. Balance Stand}

The balance stand serves the following purposes:

1. Supports the remote portion of the electronic balance so that 61-in. capsules or elements may be suspended under the balance from the weighing hook;

2. Provides a windshield to protect the subject from the movement of air through the cell ventilation system;

3. Because it can be remotely lowered, it permits the top weighing pan to be reached with a master-slave manipulator; and,

4. Provides a remotely-controlled leveling system.

The balance is leveled with a plumb-bob arrangement and adjusting pads on the base of the stand (see Figs. 6 and 8). A windshield with hinged door serves as a secondary container for fluid if density measurements are required.

Capsules and elements are suspended under the balance with a grapple that connects to the suspension weighing hook. The grapple is shown in Fig. 9.

\section{Range and Accuracy}

The specifications for range and accuracy for the balance are as follows:

1. Capacity: $1200.0 \mathrm{~g}$;

2. Tare: $300 \mathrm{~g}$;

3. Sensitivity: $0.1 \mathrm{~g}$; 


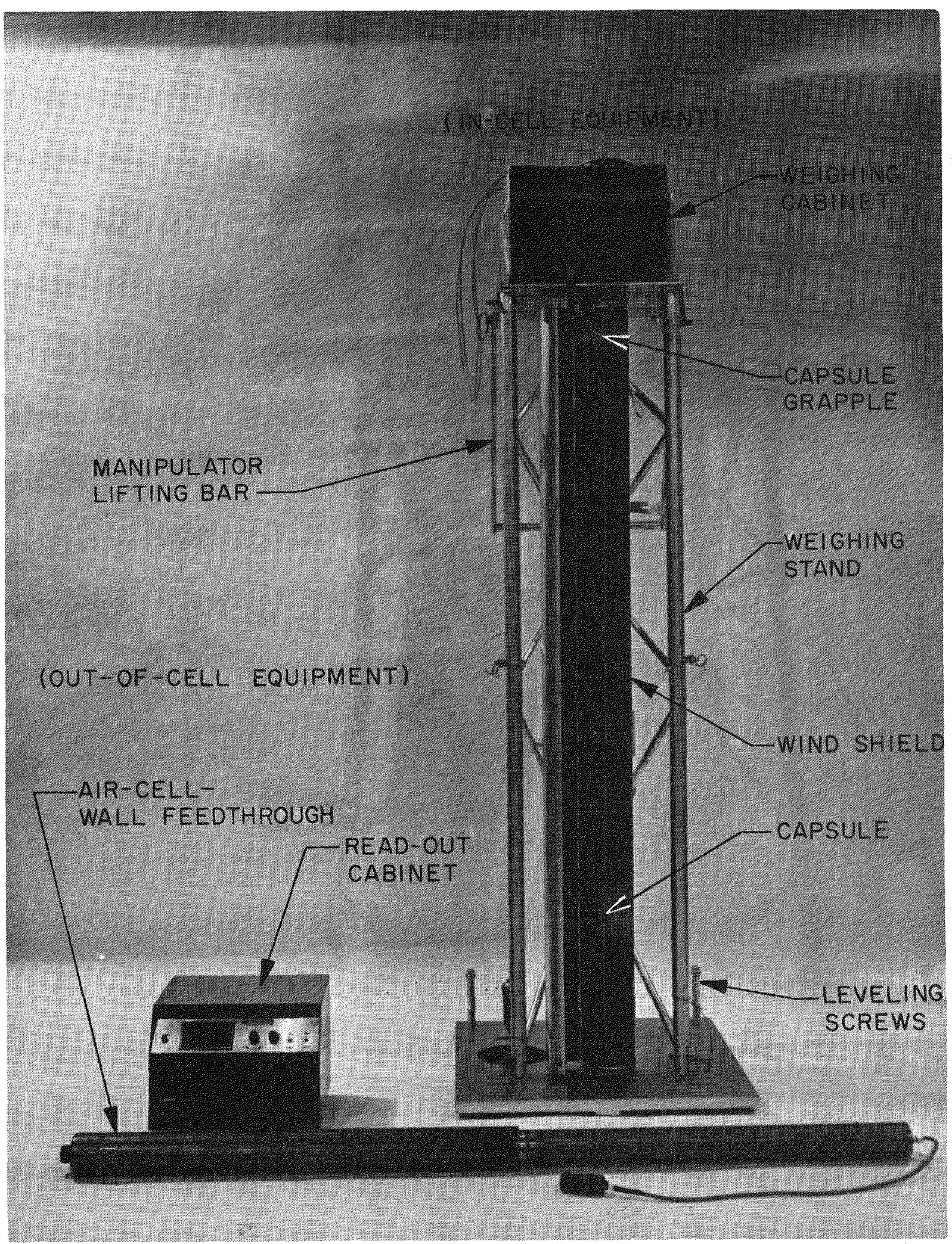

Fig. 6. Remote Balance Equipment 


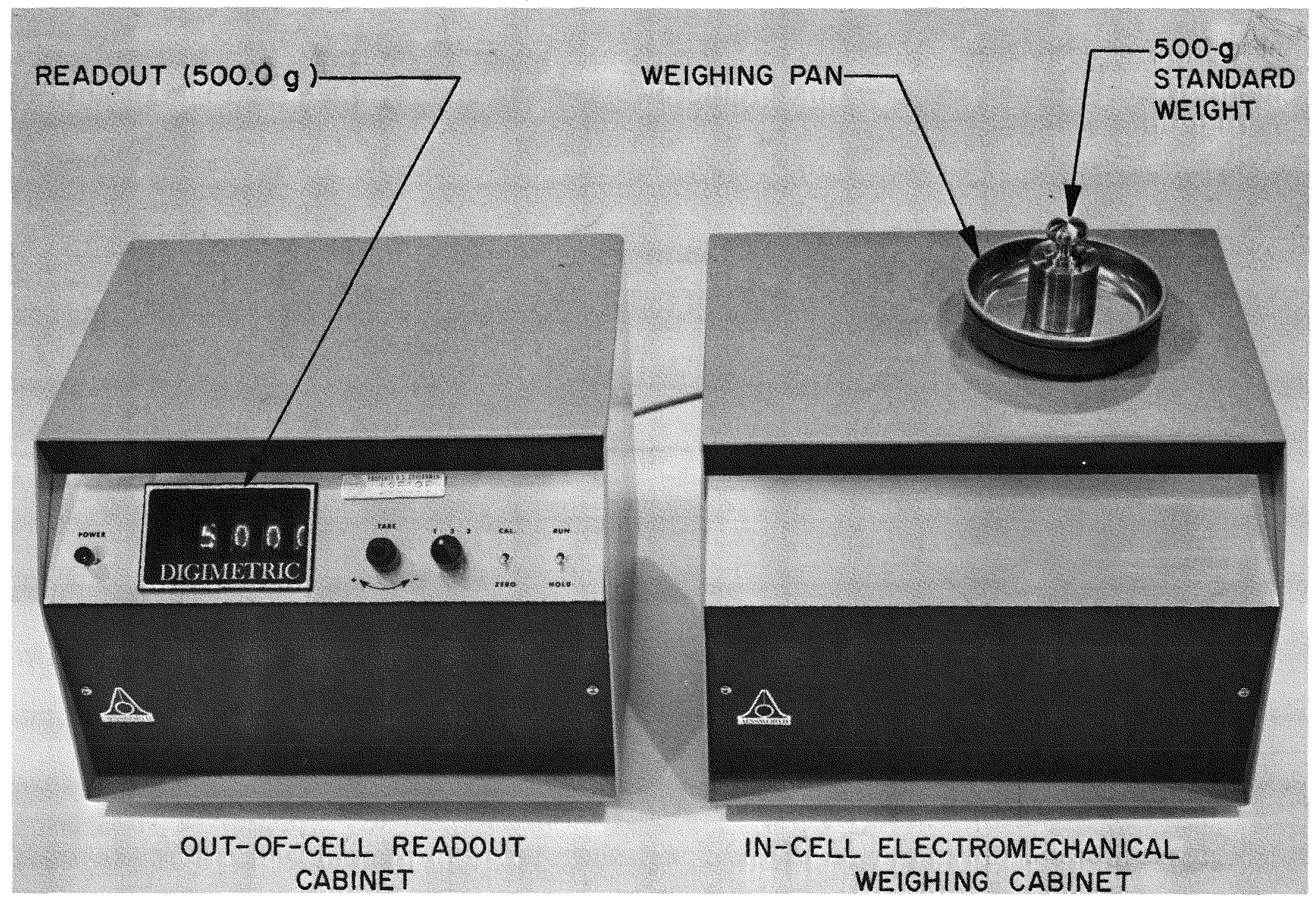

Fig. 7. Electronic Balance 

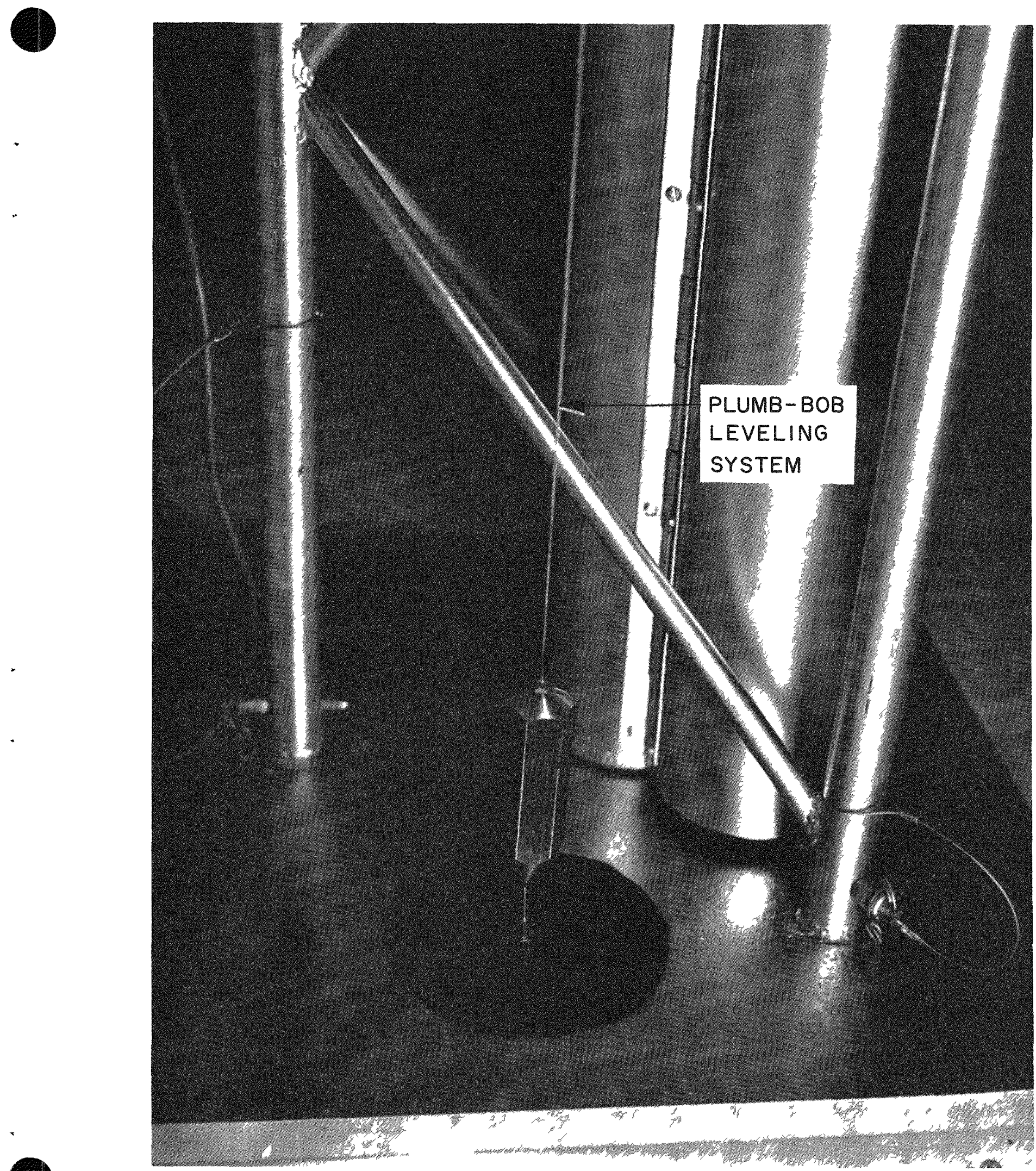

Fig. 8. Leveling System for Remote Balance Stand 


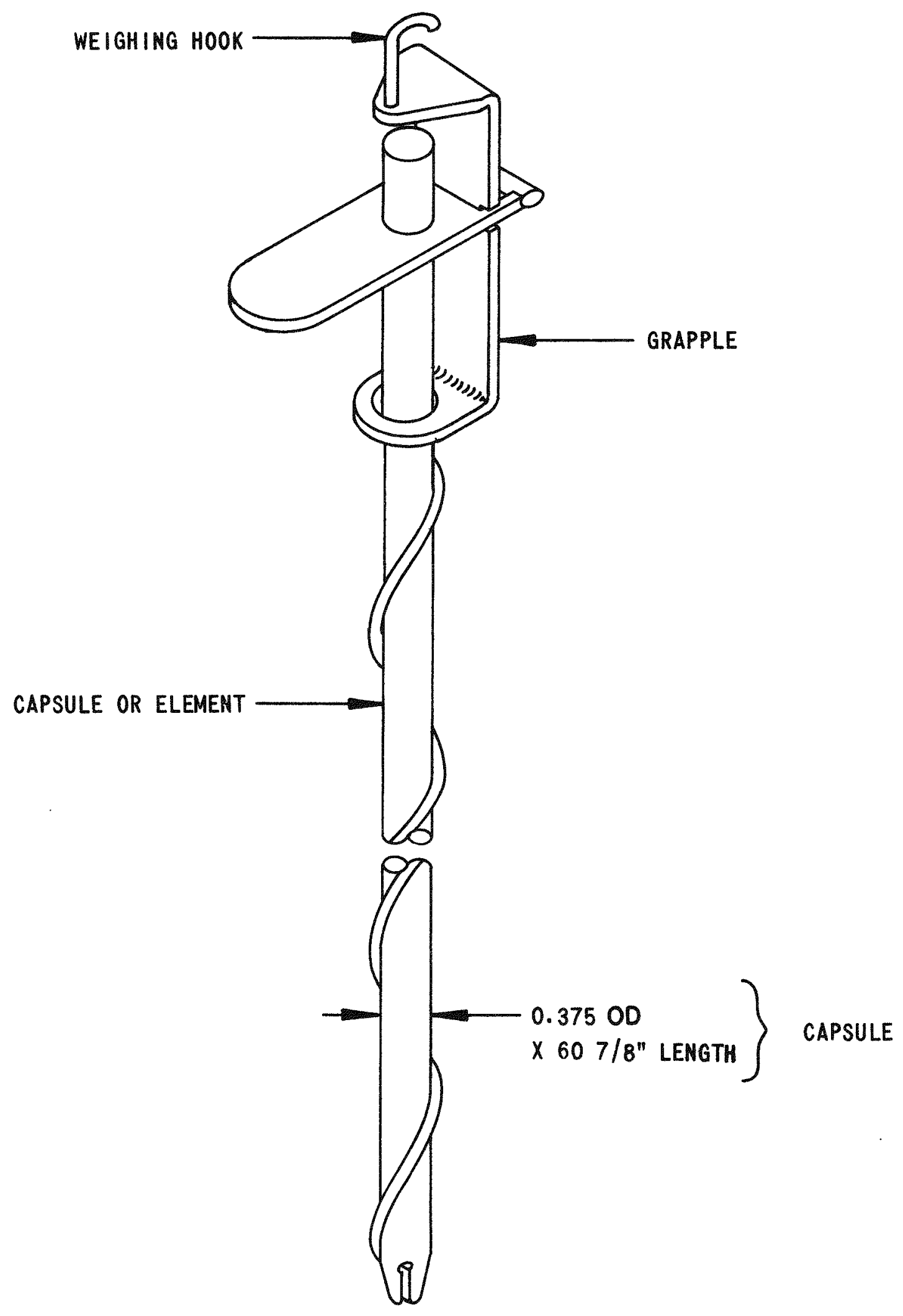

Fig. 9. Capsule and Element Grapple 
4. Reproducibility: $\pm 0.1 \mathrm{~g}$;

5. Sampling rate: $1 /$ sec;

6. Linearity: \pm 0.1 g over 1200-g capacity; and,

7. Internal calibration: $10.0 \mathrm{~g}$ against internal reference voltage.

\section{Operation}

With the balance initially leveled by using the equipment described above, an initial set-up procedure is begun. Before the power is turned on, the tare range is positioned to 1 and the tare knobs are turned full clockwise. The "calibrate-zero" switch is turned to zero and the "run-hold" switch is set to "run." At this point, the power is turned on. If overrange digit is flashing and "nixie" readout is zero, the instrument is unbalanced slightly to obtain a readout of a few grams, by turning the level supports until a positive readout is obtained.

The zero is then set by placing the "calibrate-zero" switch to the calibrate position and adjusting the tare to read $10.0 \mathrm{~g}$. The "calibrate-zero" switch is then switched to zero position, leaving tare at this setting. The balance should read all zeros with a faint flickering of the overrange lights. Because the balance is zeroed with the grapple hanging on the suspension weighing hook, it is now ready for direct operation.

The grapple is removed from the suspension weighing hook and slipped over the top end of a capsule or element. After the capsule or element is removed from the magazine, it is hung on the weighing hook. In a few seconds, a direct digital reading in grams is available.

\section{E. Weight-calibration Standards}

The balance is standardized against a set of class-"S" metric weights, which have been certified to the following accuracies: 


\section{Designation}

$1 \mathrm{~kg}$

$500 \mathrm{~g}$

$200 \mathrm{~g}$

$100 \mathrm{~g}^{*}$

$100 \mathrm{~g}$

$50 \mathrm{~g}$

$25 \mathrm{~g}$

$10 \mathrm{~g}^{*}$

$10 \mathrm{~g}$

$5 \mathrm{~g}$

$2 \mathrm{~g}^{*}$

$2 \mathrm{~g}$

$1 \mathrm{~g}$

\section{Correction, mg}

$+0.120$

$-0.250$

$+0.160$

$+0.005$

0.000

$-0.005$

0.000

$+0.010$

$-0.010$

0.000

$+0.005$

$-0.005$

0.000

*Duplicate weights.

The out-of-cell calibration indicates that the built-in electronic calibration of $10 \mathrm{~g}$ is sufficient to maintain an accuracy of $\pm 0.1 \mathrm{~g}$ over the $1200-\mathrm{g}$ range. This calibration is checked when the balance is removed from the cell for storage.

\section{FUTURE ADDITIONS TO EQUIPMENT}

\section{A. Bow and Length Equipment}

The data obtained from the equipment for measuring bow and length is in Cartesian coordinates. Obtaining the bow angle and magnitude requires subtracting the sampled coordinates from the standard coordinates and then changing the resulting $X$ and $Y$ position into polar coordinates. It is planned to replace the resistance $X$ and $Y$ encoders with digital encoders and to digitally encode the position of the scan plate. The digital output will then be transmitted to the FEF systems control room for reduction. The control cabinet will have thumbwheel switches that will be used to transmit the subassembly number and the pin identification number to the system control room. The final output of the 
data-reduction equipment will be a list of the reduced data in a form suitable for use in a report. No automatic control of this machine is planned now, although the design can be continued into this phase if found desirable.

\section{B. Remote Balance}

Because the remote balance produces only one number per subject, there is no need for automatic data reduction. The balance has performed satisfactorily in its existing configuration and probably will not be changed.

\section{REFERENCES}

1. Guide for Irradiation Experiments in EBR-II, Unpublished Document, EBR-II Project.

2. W. I. Sales, D. L. Mitche11, et al., "A Vertical Assembler-Dismantler for the Fuel Cycle Facility," Proceedings of the 17 th Conference on Remote Systems Technology, Remote Systems Technology Division of the American Nuclear Society (November 30, 1969). 